\title{
TERSON'S SYNDROME
}

\section{REPORT OF A CASE WITH FAVORABLE OUTCOME}

\author{
GIULIO CESARE PINNOLA, SÉRGIO MURILO CORREA, SÔNIA BEATRIZ F. RIBEIRO, \\ ALFREDO LEBOREIRO-FERNANDEZ, JAIME OLAVO MARQUEZ
}

\begin{abstract}
Terson's syndrome is characterized by the presence of a subarachnoid hemorrhage accompanied by retinal and vitreous hemorrhage leading to a not very favorable prognosis. We describe a case with a good outcome, probably because of a early diagnosis and medical intervention. We emphasize the routine optician's check up as very important in the evaluation of a prognosis in the cases of a suspect intracranial hemorrhage .
\end{abstract}

KEY WORDS: brain bleeding, retinal and vitreous hemorrhage, prognosis, aneurysm.

\section{Sídrome de Terson: relato de caso com evolução favorável}

RESUMO - A síndrome de Terson caracteriza-se por presença de hemorragia subaracnoídea com hemorragia vítrea e retiniana de prognóstico geralmente desfavorável. Descrevemos um caso com boa evolução provavelmente decorrente do diagnóstico e intervenções precoces. Enfatizamos a avaliação oftalmológica rotineira como de importância para avaliar o prognóstico naqueles casos com suspeita de hemorragia intracraniana.

PALAVRAS-CHAVE: hemorragia cerebral, hemorragia retiniana e vítrea, prognóstico, aneurisma .

In 1900, Terson described a syndrome characterized by a spontaneous or traumatic rupture of brain vessels, accompanied by retinal, subhyaloid, intravitreous hemorrhage which attacks one or both eyes ${ }^{2,10}$. This is due to a sudden increase of intracranial pressure which is transmitted to the cerebrospinal fluid, which in turn, is transmitted to the anterior part of the orbitary portion of the optical nerve sheath, causing compression, obstruction and stasis of both retina-choroid anastomosis and central retinal vein; therefore, there is intraocular venous pressure increase with consequent distension and rupture of papillary and retinal capillary and vitreous hemorrhage. Thereby, the postcapillary venules with their thin walls and wide lumens are particularly vulnerable to a sudden increase in intraluminar pressure. Vitreous hemorrhage was demonstrated in 3\% to $5 \%$ of patients showing with subarachnoid hemorrhage ${ }^{3-6,9}$. Walsh and Hedges found the degree of intraocular hemorrhage corresponded directly to the speed and magnitude of the development of the intracerebral bleeding and the presence or absence of cerebral edema ${ }^{10}$. Later, in the 1950s, Manschot reported that intracranial hemorrhages associated with retinal and vitreous hemorrhage had unfavorable prognosis with a $50 \%$ of mortality rate as compared to $25 \%$ in patients with no intraocular hemorrhage ${ }^{8}$. Vanderlinden and Chisholen in 1974 reported that this mortality rate was increased when intraocular hemorrhage was bilateral ${ }^{9}$. With the support of intensive care units and early neurosurgical intervention the survival rate has improved ${ }^{10}$. Usually Terson's syndrome is secondary to anterior communicant artery and internal carotid artery ${ }^{5,7}$.

Disciplina de Neurologia, Departamento de Clínica Médica, Faculdade de Medicina de Triângulo Mineiro. Aceite: 2-outubro-1997.

Dr. Giulio Cesare Pinnola - Hospital Escola FMTM - Av. Getúlio Guaritá s/nº - 38025440 Uberaba MG. FAX 0343126640. 
Ophthalmoscopy shows the following: retinal and pre-retinal hemorrhage, pigment changes of macula and adjacent retina, formation of pre-retinal membrane with or without papilla swelling ${ }^{4}$. Vitreous hemorrhage recovery is usually spontaneous in 6 to 12 months; otherwise vitrectomy is considered, although, nowadays, there is research claiming that the vitrectomy should he done earlier ${ }^{1}$.

This case report has as its purpose: 1. describe a case of Terson's syndrome with a favorable prognosis; 2. comment on ophtalmoscopic finding; 3. correlate the optician's evaluation with the prognosis.

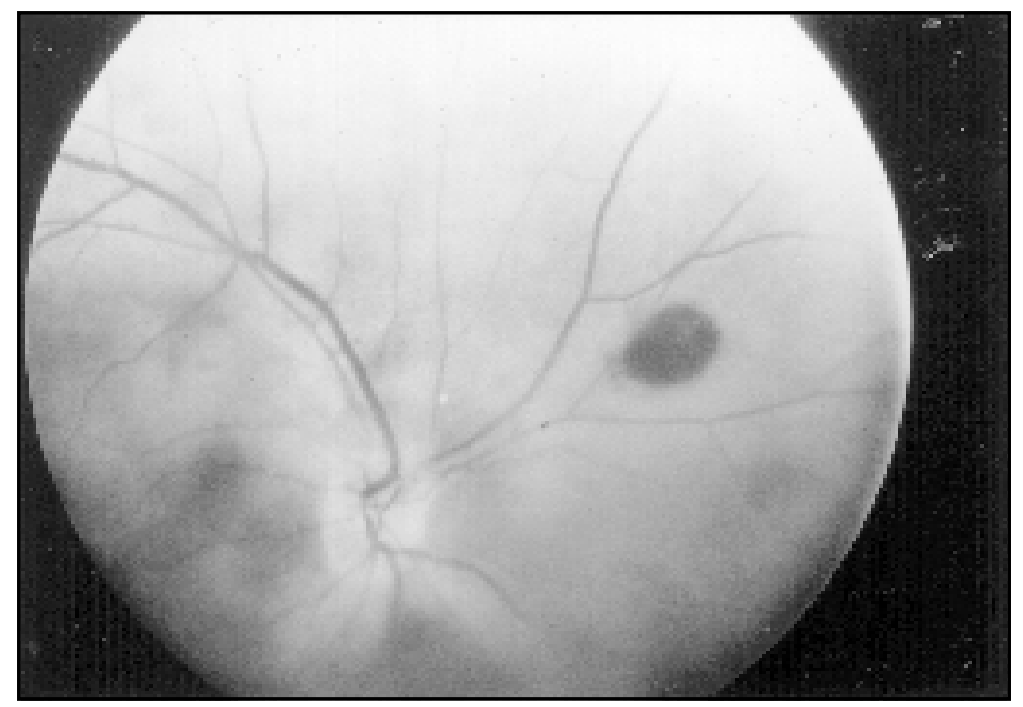

Fig 1. Right eye fundoscopy showing pigment change of peripheral retina, retinal hemorrhage and vitreous hemorrhage.

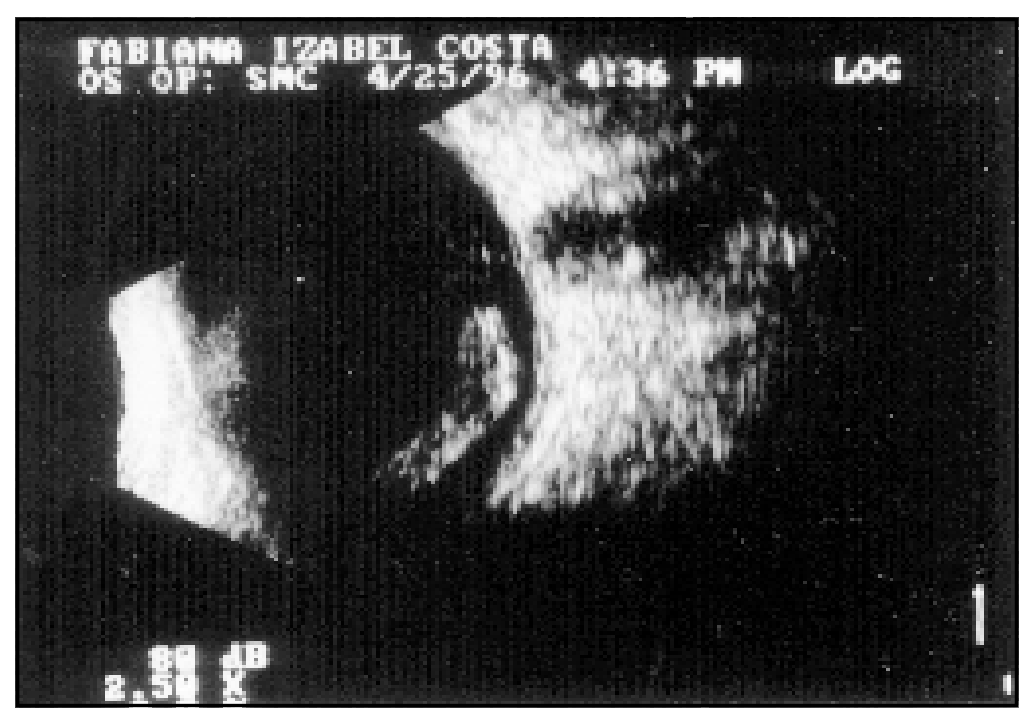

Fig 2. Ultrasonography of the left eye showing topic chrystalin, vitreous hemorrhage due to echogenic material in lower quadrants, posterior hyaloid displacement with echodense fluid pooling - blood - between hyaloid and posterior pole. 


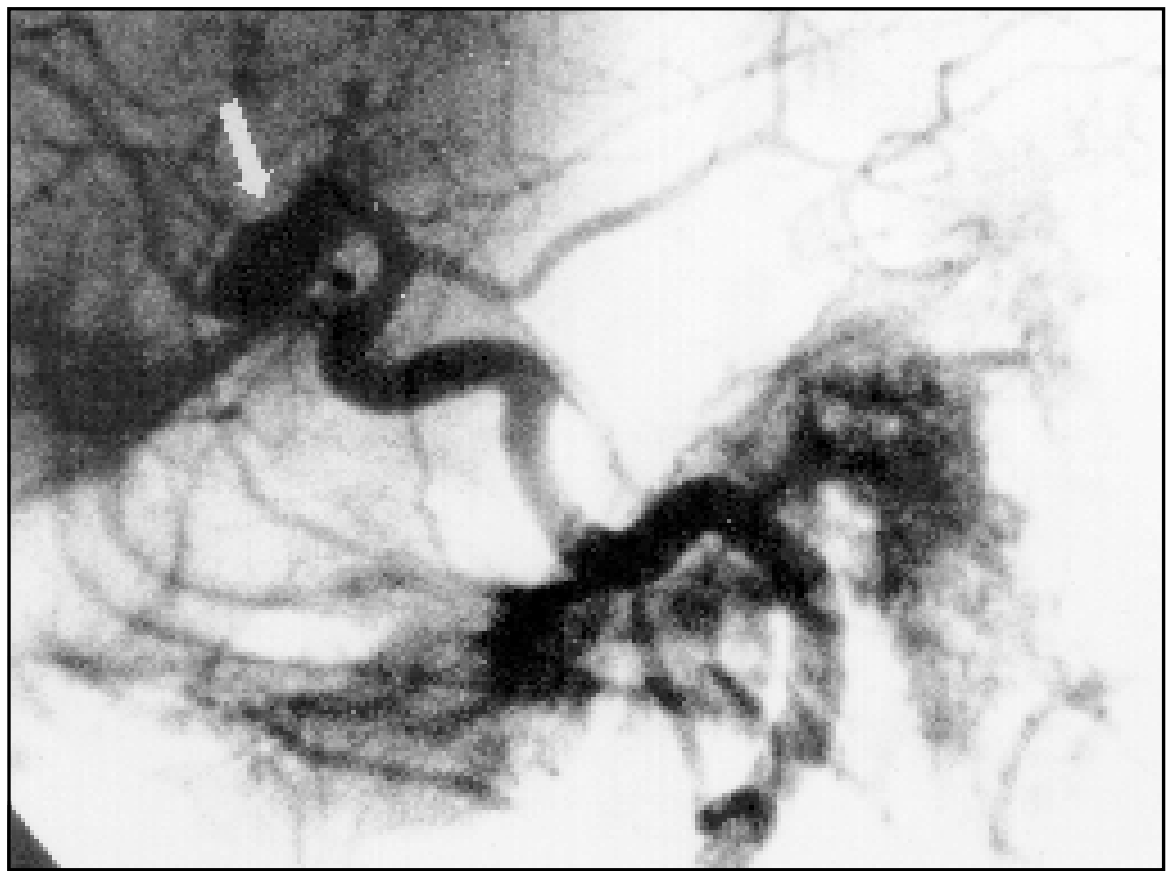

Fig 3. Cerebral angiography showing aneurysm of the right middle cerebral artery (arrow).

\section{CASE REPORT}

A female 30-years-old patient with generalized tonic-clonic seizures, followed by headache and sudden left-side vision loss, and neck stiffness. The right eye fundoscopy, showed pigment change of peripheral retina, retinal hemorrhage and vitreous hemorrhage (Fig 1). In the left eye, only vitreous hemorrhage was observed. Ultrasonography of the left eye showed (Fig 2): topic chrystalin, vitreous hemorrhage due to echogenic material in lower quadrants, posterior hyaloid displaced with echodense fluid pooling (blood) between hyaloid and posterior pole.

Computadorized tomography: no abnormalities. Cerebrospinal fluid: xanthochromic with hypercellularity $\left(10\right.$ cells $\left./ \mathrm{mm}^{3}\right)$, lymphomononuclear predominance, red cells $\left(10 / \mathrm{mm}^{3}\right)$, protein $52 \mathrm{mg} / \mathrm{dL}$, glucose $50 \mathrm{mg} / \mathrm{dL}$; spectrophotometry: bilirrubin 95\%, oxihaemoglobin 5\%, index of color 7.0; negative bacterioscopy; negative tests for syphilis, toxoplasmosis and cysticercosis.

Cerebral angiographic study showed: aneurysm of right middle cerebral artery (Fig 3 ). Aneurysm clipping was performed, and during the patient's 6 month follow-up an ophthalmologic worsening was observed, and later vitrectomy was indicated.

\section{DISCUSSION}

Terson's syndrome has been assumed as a unfavorable prognostic to intracranial hemorrhage. We believe that the satisfactory development shown by the patient has been done to the early clinical intervention on intracranial hypertension. The degree of intraocular hemorrhage corresponds directly to the speed of establishment and magnitude of the intracranial bleeding and presence or absence of a cerebral edema. This intervention, however, was not sufficient to prevent ocular damage. The patient showed and acuity visual loss after 6 months follow-up. No variable was identified to explain this unexpected favorable outcome .

It should be stressed that compromise to middle cerebral artery is relatively uncommon and when it happens, it is usually to the right side. It is necessary to investigate specifically though 
intraocular hemorrhage in patient with a suspected subarachnoid hemorrhage, because an early diagnosis could lead to aggressive management because of a bad prognosis.

\section{REFERENCES}

1. Ávila M, Cialdini AP, Crivelin M, Correa SMB. Vitrectomy in Terson's syndrome. Arq Bras Oftalm 1997;60:67-71.

2. Clarkson JG, Flynn HW, Daily MJ. Vitrectomy in Terson's syndrome. Am J Ophthalmol 1980;90:549-552.

3. Diaz AG, Carmena JJ, Martin FR, Lopez PD, Casado MJM. Intraocular hemorrhage in sudden increased intracranial pressure (Terson syndrome). Ophtalmology 1979;179:129-128 .

4. Fahmy JA. Vitreous haemorrhage in subararchnoid haemorrhage: Terson's syndrome. Acta Ophthalmol 1972;50:137-143.

5. Garfinkle AM, Danys IR, Nicolle DA, Colohan ART, Brem S. Terson's syndrome:a reversible cause of blindness following subarachnoid hemorrhage. J Neurosurg 1992;76:766-771.

6. Giangiacomo J, Barkett KJ. Ophthalmoscopic findings in occult child abuse. J Pediat Ophthalmol \& Strabismus 1985;22:234-237.

7. Schultz PN, Sobol WM, Weingeist TA. Long - term visual outcome in Terson syndrome. Ophtalmology 1991;98:1814-1819.

8. Walsh FB, Hoyt WF. Clinical neuro - ophtalmology. Baltimore: Williams \& Wilkins, 1969.

9. Weingeist TA, Goldman EJ, Folk JC, Packer AJ, Ossoinig KC. Terson's syndrome: clinicopathologic correlations. Ophthalmology 1986;93:1435-1442.

10. Velikay M, Datlinger P, Stolba U, Wedrich A, Binder S, Hausmann N. Retinal detachment with severe proliferative vitreoretinopathy in Terson syndrome. Ophthalmology 1994;101:35-37. 